\title{
The environnemental quality of soil under wheat and vinesin the region of Mohammadia Benslimane (Morocco)
}

\author{
Zaakour Fatna ${ }^{1,}$, Saber Najib ${ }^{1}$, Ismaili Alaoui Diyae ${ }^{2}$, AndBen Hachmi Mohammed Karim ${ }^{2}$ \\ ${ }^{1}$ Laboratory of Sustainable Agriculture Management, Higher School of Technology Sidi Bennour, Chouaib Doukkali University El Jadida, \\ Morocco \\ ${ }^{2}$ Laboratory of Processes and Environment Engineering, Faculty of Sciences and Techniques Mohammadia (Morocco)
}

\begin{abstract}
This work aims to assessing the environmental quality of agricultural soils under vine and wheat cultivation in the area of Mohammadia-Benslimane (Morocco). 80 soil samples were collected and studied. The results have been studied and recorded on the agronomic parameters; show that the soil's textures contain clay andthe values of $\mathrm{pH}$ are neutral to slightly acid in all stations. The electrical conductivity values are clearly higher in soils under wheat than in those under vine. The $\mathrm{CaCO} 3$ contents within the different studied soils are generally similar in all stations. Moreover, the organic substance rate seems to be more important in the soils under the wheat crops $(2 \%)$ than in those under the vine crops $(1,7 \%)$. For the four analyzed elements: Cadmium $(\mathrm{Cd})$, copper $(\mathrm{Cu})$, lead $(\mathrm{Pb})$, and zinc $(\mathrm{Zn})$, the lead and the zinc present a high concentration in the vine yard Plots compared to those of the wheat. The concentrations of the Cadmium in a few stations exceed the standards ( $2 \mathrm{ppm})$ and can reach 10,37 ppm. The order of the average's contents with the lead and the zinc are 20,12 ppm and 148,60 ppm, respectively. They are inadequate with the concentration standards for a normal soil, ie $100 \mathrm{ppm}$ for $\mathrm{pb}$ and $300 \mathrm{ppm}$ for zinc. As regards metallic pollution, its index increases, for the soil under the vine (it takes the values from 0.281 to 2.203 ).
\end{abstract}

\section{Introduction:}

The contaminations of soils with the heavy metals have become one of the major environmental problems around the world $[1,2,3,4]$.It becomes a source of danger to the health of people, even to those living in the cities $[5,6$, 7]. The anthropogenic pollution iscaused by the heavy industries which in the enters plants, then it goes through the food chain and ultimately endangers the human health $[8,9,10,11,12]$. In addition, by the wind, the top layer of the soil can be easily resuspended, as a dust particle and it can be inhaled. It is well known that the toxic elements tend to accumulate in the smallest particle size fractions of the soils [13].

The most common heavy metals found at contaminated sites, in order of abundance are $\mathrm{Pb}, \mathrm{Cr}, \mathrm{As}, \mathrm{Zn}, \mathrm{Cd}, \mathrm{Cu}$, and $\mathrm{Hg}[14]$. The heavy metals such as $\mathrm{Cd}$ and $\mathrm{Pb}$ havecarcinogenic effects $[15,16]$.

Other metals such acopper and zinc are essential nutrients for the human health, but they can be toxic at high concentrations [3]. For example, $\mathrm{Zn}$ can reduce the immune function and the levels of high-density

\footnotetext{
*Corresponding author: zaakour-fatna@hotmail.com
}

lipoproteins [17]. It is also found that, $\mathrm{Cu}$ can cause an acute stomach, intestine aches and liver damage [18].Research on soil quality in Morocco is a topical issue and it is a part of the sustainable development policy envisaged by the national authorities, particularly, in its new agricultural policy "Green Morocco Plan".On a contemporary map of key wine producing areas around the world. Morocco and its North African neighbours would hold a less than prominent position. Recently, in Morocco, it is estimated the size of vineyards specifically for wine grapes: 10000 hectares, it dwarfed by both major European and New World producers alike Morocco is however a country with potential for quality winemaking, even the prominent religious and political difficulties. The country is still coming to terms with its colonial past and it is this legacy which continues to influence wine-making within Morocco as significantly now as it has done for the last hundred years. The first cultivated grapes were probably introduced to Morocco by Phoenicians and Carthaginians [19, 20]. Those introductions, and their putative derivatives resulting 
from hybridization among cultivated and wild forms, could represent the oldest cultivated vines in the region, truly commercial viticulture was introduced to the country in the early twentieth century with the arrival of French colonists in 1912[21]. Under their efforts land under vineyard swelled to 50000 hectares by the midtwentieth century with traditional southern French varieties including Carignan and Cinsault making up the majority of plantings.

The evolution of areas occupied by vine growing over the last 20 years has been characterized by a decline in both types of vineyard land in favor of cereals.

The Moroccan vineyard covers a total area of 50000 ha in 2006 and 2011 viticulture occupied an area of 48000 ha [22]. With an area of cultivation of 44600 ha in 2017 , grapevines rank fourth among fruit crops of Morocco and represent one of the most valuable crops for the country's economy[23].

In the region of Mohammedia Benslimane (Morocco), we found that vineyards have declined in favor of wheat growing. The evolution of areas occupied by vine growing over the last 20 years has been characterized by a decline in both types of vineyard land in favor of cereals. This change in rotation would have an impact on the quality of the soil in this region[24].

The aims of this study are to identify the soil characteristics in the agricultural soils under the vine and the wheat in the region of Mohammadia Benslimane (Morocco)and estimate the trace element in the soil under the vine and the wheat. In addition, analyzingthe pollution index and the correlation between the organic parameters and heavy metals.

\section{Materials and methods}

The area of this study belongs to the provinces of Mohammadia and Benslimane cities located on the Atlantic coast of Morocco (figure 1). This area is located between the cities of Rabat and Casablanca,This region is characterized by a semi-aridMediterranean climate. The annual rainfall average of the last 20 years is $400 \mathrm{~mm}$. The oceanic influence creates a variation at the level of the forest microclimate[25].Throughout this work, 8stations within the region of Mohammadia Benslimane are our main field of study. We have examined 10 samples in each station in the horizon $[0-20 \mathrm{~cm}]:(5$ samples under the cultivation of the wheat and the other ones under the vine).

After transportation to the laboratory, the soil sampling was air-dried and sieved through $<2 \mathrm{~mm}$ mesh. Subsamples were used to measure the physical-chemical properties according to the standard procedures.

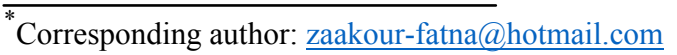

The analysis of the texture in the various stations is determined by the Robinson pipette method [26] and the analysis of the organic matter has been conducted using [27]method.The electrical conductivity in the method of 28$]$, the soil $\mathrm{pH}$ was measured with $\mathrm{H}_{2} \mathrm{O}$ (1:2.5 ratio) method of [29] while the dosing of $\mathrm{CaCO}_{3}$ was made by the method of Bernard [30].

Concerning the heavy metal concentrations, the soil was extracted by aqua regia at $160-\mathrm{C}$. Then the metal concentrations in the digests were determined by the inductively coupled plasma-optical emission spectrometry.

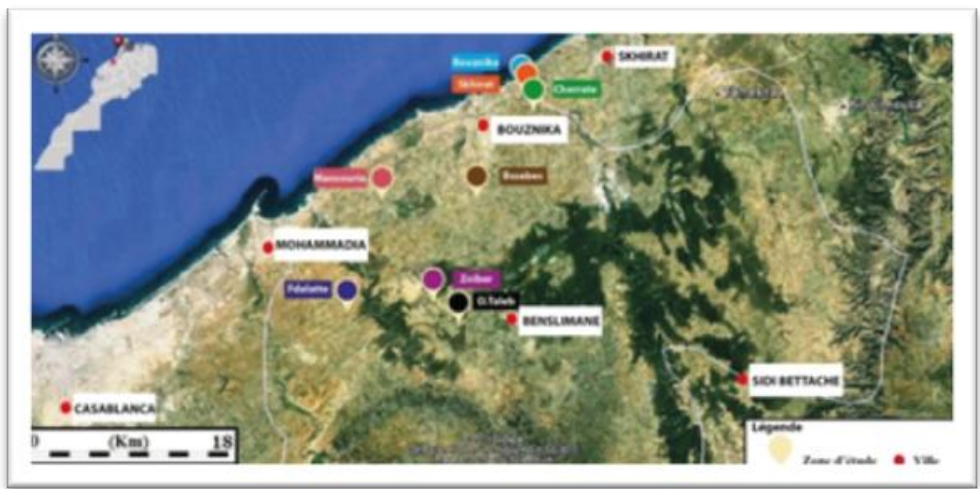

Figure 1: The location of the studied area

\section{Results and discusion \\ 2.1. Characterization of the studied soils}

The granulometric analysis of the different stations revealed a clay texture for the Bouznika, Bssabes, Cherrat, Fdalate, Mansouria and Skhairate area, silty clay in the Zniberdomain and silt loam in the station of Ouled Taleb (figure 2).

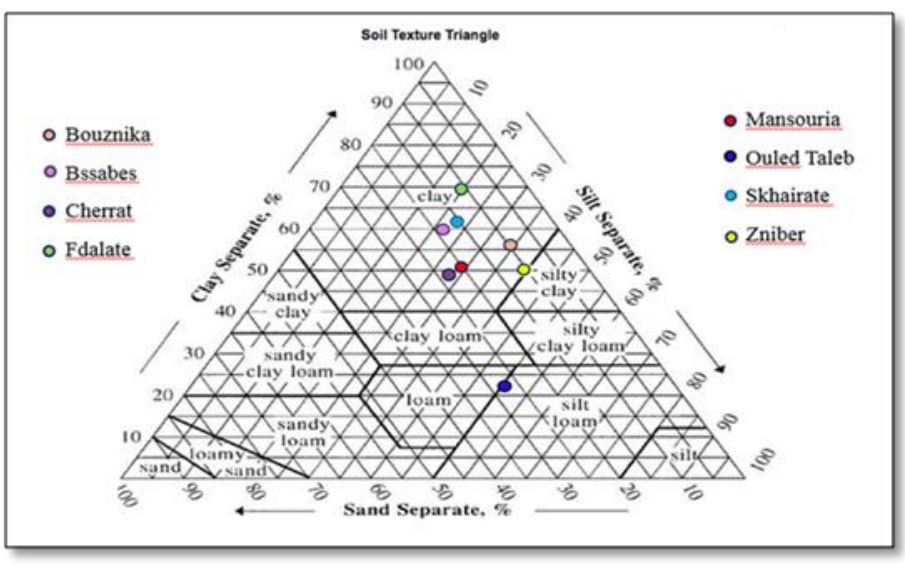

Figure 2: The texture of the soils in the areas of Mohammadia Benslimane, Morocco 
The $\mathrm{pH}$ is considered as the main chemical parameter controlling the bioavailability of the heavy metals in the soil [31].

The $\mathrm{pH}$ results in this study show that, the values are neutral to slightly acid in allstations. The values of the $\mathrm{pH}$ measurements arerecorded in the soils under the wheat cultivation are higher in comparison with the soils under the vine cultivation with the exception of Fdalate (figure 3).

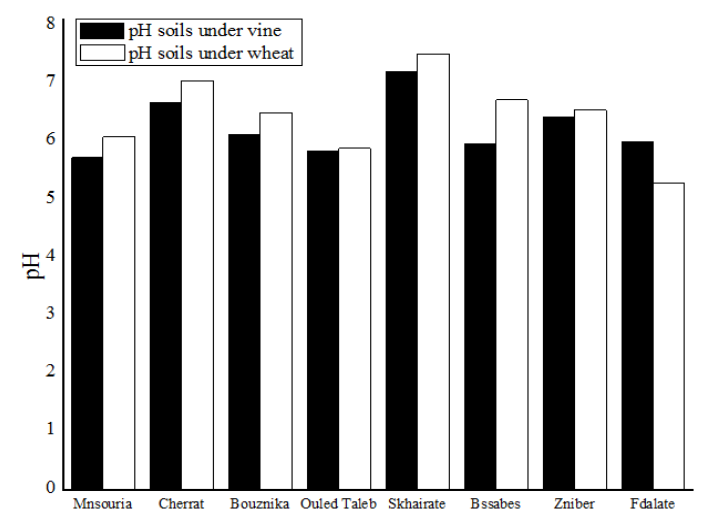

Figure 3: The studiedsoil $\mathrm{pH}$ according stations

Figure 4 shows the electrical conductivity of the soils in the studiedstations. It is clearly seen that, the measurements of the electrical conductivity in the soil stations of Mansouria, Bouznika, Ouled Taleb and Fdalateare lower than those of Cherrat, Skhairate and Bssabes. The measurements in soils under the wheat cultivation are higher than those ofthe soil vine.

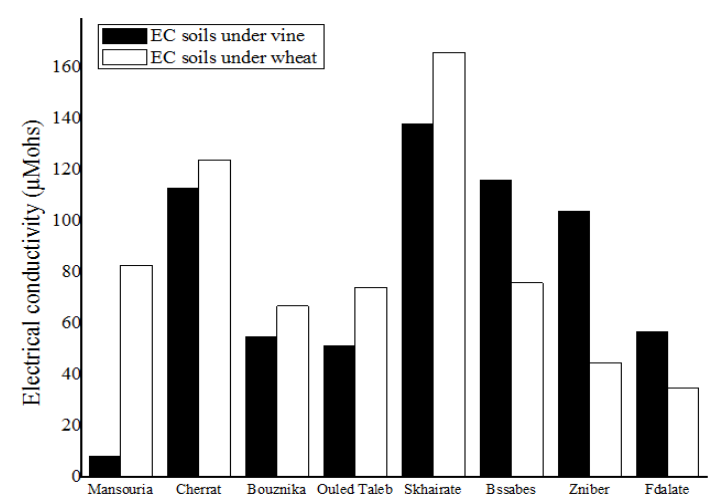

Figure 4: The electrical conductivity of the soils in the studiedstations

It is seen from figure 5 which exhibits the $\mathrm{CaCO}_{3}$ concentration in the studied soils that, the values of $\mathrm{CaCO}_{3}$ are comparable under the wheat and the vine in the stations of Mansouria, Bouznika, Ouled Taleb and

*Corresponding author: zaakour-fatna@hotmail.com
Skhairate. While these values can vary in the stations of Bssabes, Zniber and Fdalate.

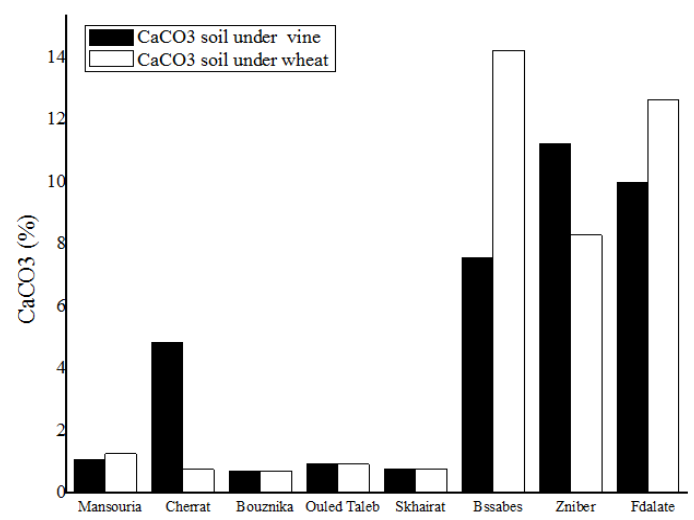

Figure 5: The $\mathrm{CaCO}_{3}$ concentration in the studiedsoils

Moreover, the average rate of the total organic matterin the wheat plots is higher $(2.93 \%)$ than under vine $(1.7 \%)$ with the exception of the plot of land under wheat in Skhairate where there is a supply of organic fertilizer(figure 6).

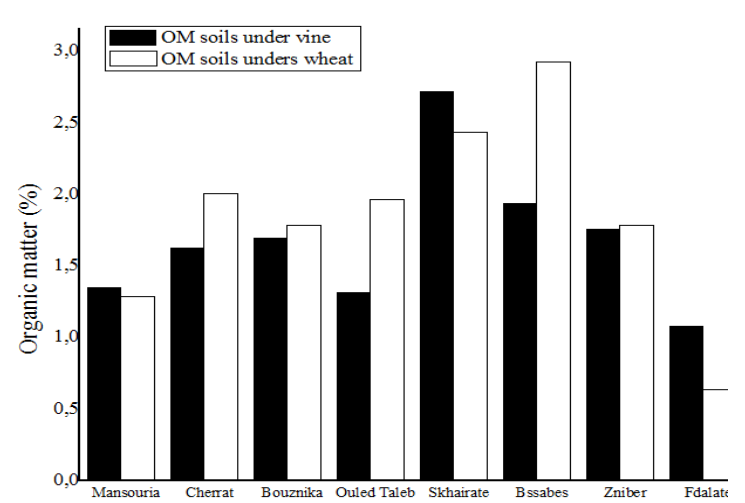

Figure 6: Soil organic matter content

2.2. Soil pollution in $\mathrm{Cd}, \mathrm{Cu}, \mathrm{Pb}$ and

The concentration of the metal trace elements (MTE) which is measured in the soil is the outcome of the heritage created by alteration of the rock concentrations (local geochemical background), more or less altered by soil formation process (soil geochemical background). This background is enhanced by the contributions of the human activities [32].

Figure 7 presents the values of the aluminum levels which is higher in the vine yard soils $(4,25-106,62 \mathrm{~g} / \mathrm{Kg})$ compared to the wheat soils $(3,55-30,4 \mathrm{~g} / \mathrm{Kg})$ in all stations except Cherrat, Fdalate and Zniber with 
significantdifference between soils under the vines andthose under the wheat.The values of the aluminum contents are very high in the Mansouria, Cherrat, Bouznika, Ouled Taleb and Skhairate and are lower in Bssabes, Zniber and Fdalate stations.

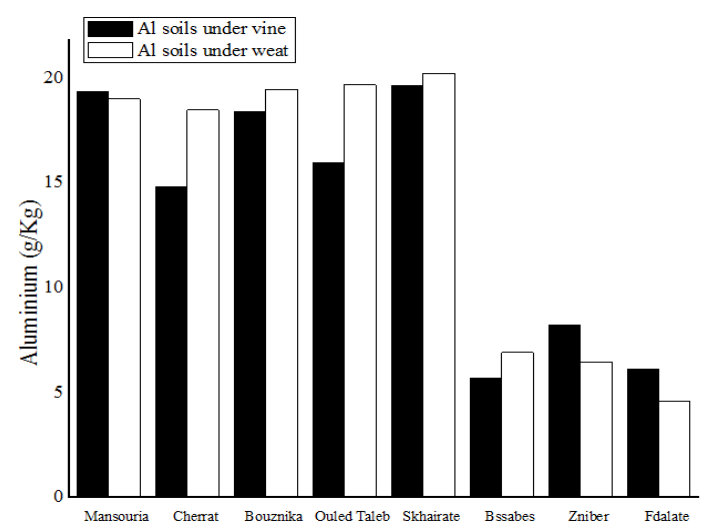

Figure 7: Concentration of aluminium in soils under the vine and the wheat on the studiedsites

Figure 8 shows the soil concentrationsof $\mathrm{Fe}$ which are comparable between the soils under the vines and under the wheat in Mansouria, Bouznika, Cherrat, Ouled Taleb and Skhairate. These levels are very low compared with the maximum average levels recommended by OMS $(0,01-50 \mathrm{~g} / \mathrm{kg})$. These values permitted to detect an iron deficiency in these soils.

Iron deficiency can be induced when the value of $\mathrm{pH}$ of the soil is high, during bad aeration, or when there are high levels of zinc $[33,34,35,36,37]$ and this is the case of our soils. Cereal crops are considered by several authors quite insensitive to iron deficiency and this is the case of our soils. Cereal crops are considered by several authors quite insensitive to iron deficiency[38]. On the other hand, the vine is more sensitive, the ferric chlorosis mainly affects the young plantations of two to three years[39].

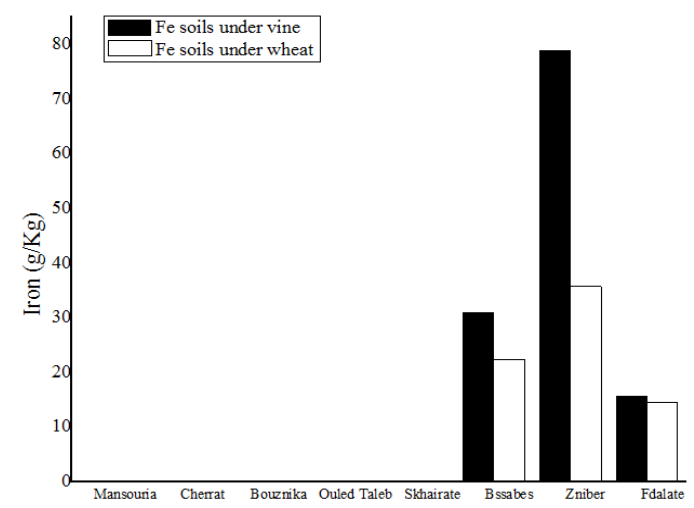

Figure 8:Concentration of iron in soils under the vine and the wheat on the studiedsites

*Corresponding author: zaakour-fatna@ $@$ hotmail.com
The cadmium is one of the most ecotoxic metals with very negative effects on the soil biological activity, plant metabolism, human and animal health [40].

The maximum cadmium values were recorded in wheat soil of the Zniber area with a content of $10.375 \mathrm{ppm}$ in the vineyard soils of Bssabes (5.331 ppm) and Fdalate (15.579 ppm). While alow level of the cadmiumwas observed in the Mansouria (0.64 ppm), Cherrat(0.63 ppm), Bouznika (0.61 ppm), Ouled Taleb (0.72 ppm) and Skhairate(0, 52ppm) (figure 9).

From neutral to slightly acidic $\mathrm{pH}, \mathrm{Cd}$ is less mobile because of its high affinity with organic matter and soil nutrients (NPK) [41, 42, 43, 44]. This could explain the high $\mathrm{Cd}$ concentrations that are probably due to the inputs of manure and phosphate fertilizers rich in $\mathrm{Cd}$. In addition, the $\mathrm{Cd}$ affinity for $\mathrm{CaCO}_{3}$ was confirmed in the different works of [41].

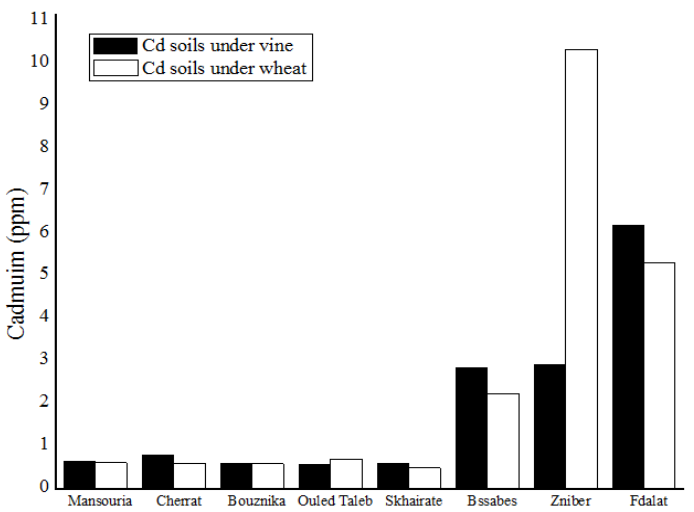

Figure 9:Concentration of cadmium in soils under the vine and the wheat on the studiedsites

Fungicide treatments of the vines have been based primarily on the salt spray of the copper $(\mathrm{Cu})$ on the vine leaves. Their widespread use since the late 19th century has led to the pollution of $\mathrm{Cu}$ that resulted in risks such as the $\mathrm{Cu}$ phytotoxicity which threatens the plants grown in these soils[45].

In our study, the soil under the vine shows high or very high levels of $\mathrm{Cu}$ compared with the other under the wheat. The maximum concentrations of $\mathrm{Cu}$ were recorded in the soils of Ouled Taleb (66.70 ppm).The difference in copper concentrations between stations is highly significant(figure 10).

The copper can cause phytotoxicity in vine-planted soils that have been treated with copper salt, which has been used as a fungicide for many years. Then it induces ferric chlorosis and decrease Fe absorption. The vine does not suffer because its root system mainly explores the soil in 
depth whereas $\mathrm{Cu}$ enrichment occurs in the first centimeters.

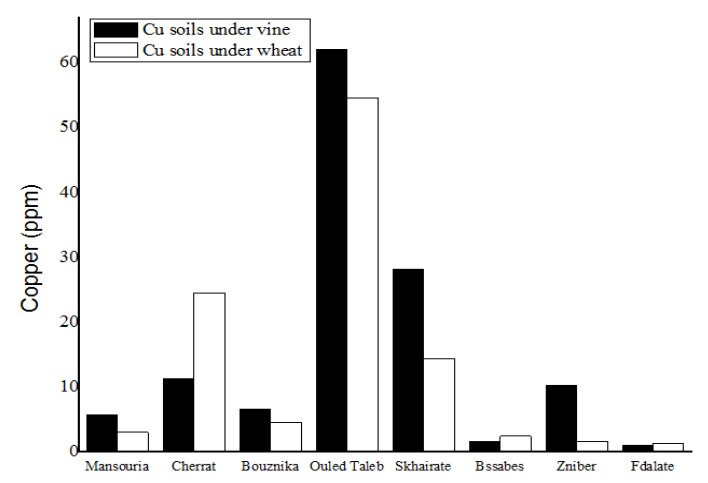

Figure 10:Concentration of copper in soils under the vine and the wheat on the studiedsites

The maximum lead levels are recorded in the vineyard soils in Zniber area (119.32 ppm).It exceeds the normal threshold value for the uncontaminated soils (100 ppm) set by OMS.

This result explained by the fact that $\mathrm{Pb}$ is not very mobile,since it is mainly associated with the clays and the organic matter, it is mobile only when it forms soluble organic complexes and / or when the soil has exceeded its absorption capacity for $\mathrm{Pb}[46,47,48]$.

We have given in figure 11 the lead levels which are found in the other stations.it is see that the concentration of lead do not exceed the value $67.14 \mathrm{ppm}$. The difference in lead concentrations between the vineyard and the wheat plots is highly significant for all stations. Thus, the maximum concentration of lead is recorded in soils under the vineyardswhich are treated in the traditional way (from 40.84 to $67.14 \mathrm{ppm}$ ), while the areas of Mansouria and Bouznika show a low level of lead with an average varying from 38.36 to $40.84 \mathrm{ppm}$. The difference in lead concentrations between plots of the vine and the wheat is highly significant in all stations.

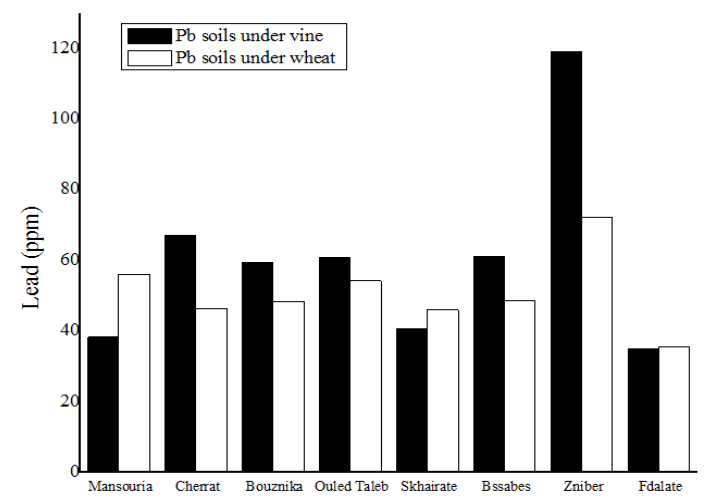

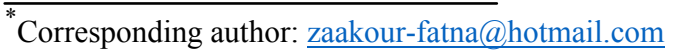

Figure 11:Concentration of lead in soils under the vine and the wheat on the studiedsites

The Zinc substance which is an essential element for low dose. However, it causes an acute toxicity with a high dose [49]. The zinc, which is also an essential low-grade element, causes acute high-dose toxicity.

In our study, the average concentrations in the vineyard soils are higher than those in the wheat soils in all stations. The difference in zinc concentrations between vineyard and the wheat plots is highly significant in the Mansouria, Cherrate,Skhairate,Zniber and Fdalateareas.

The average concentrations in vineyard soils of $\mathrm{Zn}$ are below the standard set by OMS (300 ppm) in Bouznika, Ouled Taleb, Shkairate, Bssabes, Zniber and Fdalate estates when they exceed the standard value (300 ppm) at Cherrate (274 - 378.35 ppm) and Mansouria (261.98 $791.63 \mathrm{ppm}$ )(Figure 12). This decrease can be explained by the solubility and mobility of this soluble element relative to the other heavy studiedmetals.

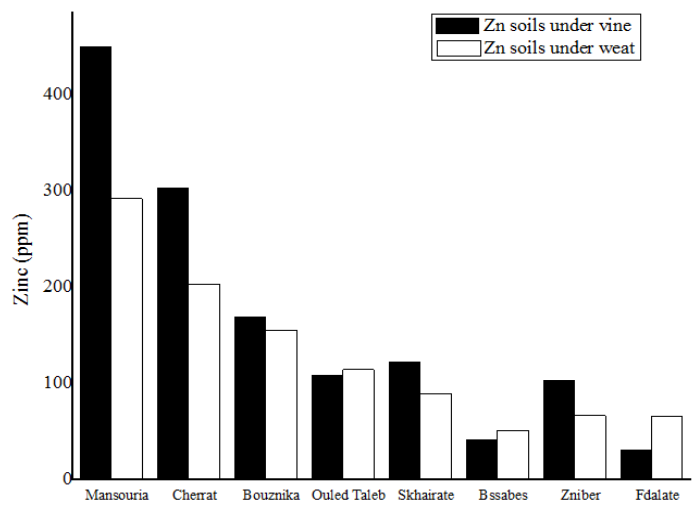

Figure 12:Concentration of zinc in soils under the vine and the wheat on the studiedsites

\subsection{Pollution index}

The heavy metal contamination on the environmental surface is associated with all contaminants rather than just one metal. Several au

thors have introduced the soil pollution index to identify the multi-element contamination that results from an increase in the metal toxicity $[50,51,52]$.The pollution index is defined as the average ratio of the metal concentrations in the soil samples to the limit values [53].

The spatial variation of the pollution index in the region of Mohammedia Benslimane region indicates a maximum values which are observed at the Fdalate station $(1,447$ for the vineyard soils and 0,683 under 
wheat),Bssabes (1,094 recorded in vineyard soils and 0.814 in wheat) and the Zniber estate (2,203 subvineyard soils and 1,947 under wheat).In fact, the soils of these two stations exhibit a high cadmium concentrations equal to $15.57 \mathrm{ppm}$ (Fdalate station) and $19.27 \mathrm{ppm}$ (Zniber domain) and lead 46.66 ppm (Fdalate station) and 182.26 ppm (Zniber domain)(Figure 13).

We have found in all stations that the pollution index is higher in soils under the vines than the soils under the wheat. Thepollution indexes clearly increase in thestations of Zniber and Fdalate. These trends can be explained by the location of those three situationswhich isnear the roador the treatment with phosphate fertilizers rich in $\mathrm{Cd}$ and the pedo-geo-chemical background of these stations.

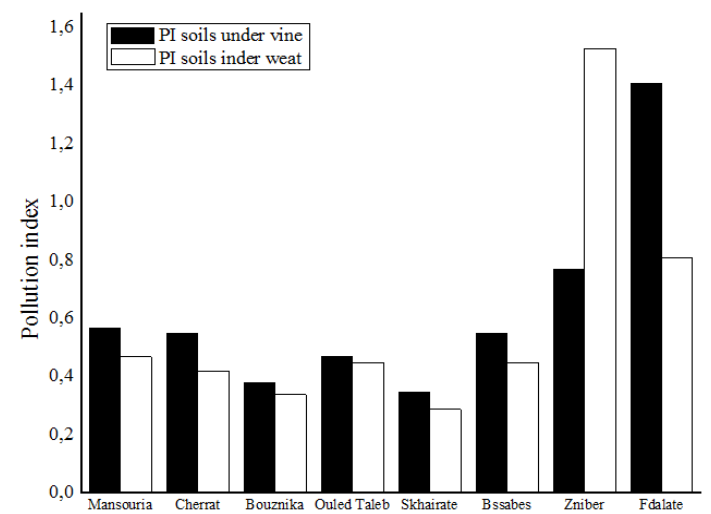

Figure 13: Indices of the pollution soils under the vine and the wheat in each station

\section{Conclusion}

For the agronomic characterization of the studied soils, we canconclude that the electrical conductivity, the $\mathrm{pH}$ and the organic matterhave a high value in the soils under the wheat compared tothose of the soils under the vines. This tendency can be in one part, influenced by the residue nature of the agriculture contribution to soil and in another part;it can be influenced by thefarm manure contribution.

The Iron deficiency was recorded in the Mansouria, Bouznika, Cherrat, Ouled Taleb and Shkairate stations. The evaluation of the soil contamination under the vines and the wheat, by trace metal elements $\mathrm{Cd}, \mathrm{Cu}$, $\mathrm{Zn}$ and $\mathrm{Pb}$ in the region of Mohammedia Benslimane, shows that, the soils of the zone have ahigh level compared to the normal levels of uncontaminated soils. This pollution varies according to the field and the pollutants. A high availability of these pollutants in the soil would present a real health risk.

*Corresponding author: zaakour-fatna@hotmail.com
This study particularly revealed a very high pollution index in the stations of Zniber and Fdalate compared to the other ones.

\section{References}

1. Radwan, M.A., Salama, A.K., Market basket survey for some heavy metals in Egyptian fruits and vegetables. Food Chem. Toxicol. 44 (8), 1273-1278 (2006).

2. Khan, S., Rehman, S., Khan, A.Z., Khan, M.A., Shah, M.T., Soil and vegetables nrichment with heavy metals from geological sources in Gilgit, northern Pakistan. Ecotoxicol. Environ. Saf. 73, 1820-1827 (2010).

3. Rahman, M.A., Rahman, M.M., Reichman, S.M., Lim, R.P., Naidu, R., Heavy metals in Australian grown and imported rice and vegetables on sale in Australia: Health hazard. Ecotoxicol. Environ. Saf. 100, 53-60 (2014).

4. Gratão, PL., Monteiro, CC., Tezotto, T., Carvalho, RF., Alves, LR., Peters, LP., Azevedo, RA., Cadmium stress antioxidant responses and root-to-shoot communication in grafted tomato plants. Biometals 28(5):803-816 (2015).

5. Li,X., Shen, Z., Wai, OWH., Li, YS., Chemical forms of $\mathrm{Pb}, \mathrm{Zn}$ and $\mathrm{Cu}$ in the sediment profiles of the Pearl River Estuary. Mar Pollut Bull 42(3):215-223 (2001).

6. Manta, D.S., Angelone, M., Bellanca, A., Neri, R., Sprovieri, M., Heavy metal in urban soils: a case study from the city of Palermo (Sicily), Italy. The Science of the Total Environment, 300: 229-243 (2002).

7. Komarniki, G.J.K., ad and cadmium in indoor air and the urban environment. Environmental Pollution, 136: 47-61 (2005).

8. Kim N., Fergusson, J., Concentrations and sources of cadmium, copper, lead and zinc in house dust in Christchurch, New Zealand. The Science of the Total Environment, 138: 1-21 (2001).

9. Gupta, S.K., Vollmer, M.K., Krebs, R., The im- portance of mobile, mobilisable and pseudo total heavy metal fractions in soil for three-level risk assessment and risk management. The Science of the Total Environment, 178: 11-20 (1996).

10. Charles Worth, S., Everett, M., Mc Carthy, R., Or-Donez, A., Miguele, E., A comparative study of heavy metal concentration and distribution in de-posited street dusts in a large and small urban area: Birmingham and Coventry, West Midlands, UK. Environment International, 29: 563-573 (2003). 
11 .ImperqtoM., Adamo P., Naim D., Arienwo M., Stan- zione D., Violante P., Spatial distribution of heavy metals in urban soils of Naples city (Italy). Environmental Pollution, 124: 247-256 (2003).

12. Liu, GN., Wang, J., Zhan, EX., Hou, J., Liu, XH., Heavy metal speciation and risk assessment in dry land and paddy soils near mining areas at Southern China. Environmental Science and Pollution Research 23(9):87098720. doi: 10.1007/s11356- 016-6114-6 (2016).

13. Alghobar, M.A., Suresha, S., Evaluation of metal accumulation in soil and tomatoes irrigated with sewage water from Mysore city, Karnataka, India. J. Saudi Soc. Agric. Sci. 16, 49-59 (2017).

14. USEPA, Report: recent Developments for In Situ Treatment of Metals contaminated Soils, U.S. Environmental Protection Agency, Office of Solid Waste and Emergency Response (1996).

15. Jaishankar, M., Tseten, T., Anbalagan, N., Mathew, B.B., Beeregowda, K.N., Toxicity, mechanism and health effects of some heavy metals. InterdiscipToxicol. 7 (2), 60-72 (2014).

16. Kachenko, A.G., Singh, B., Heavy Metals Contamination in vegetables grown in urban and metal smelter contaminated sites in Australia. Water Air Soil Pollut. 169, 101-123 (2006).

17. Harmanescu, M., Alda, L.M., Bordean, D.M., Gogoasa, L., Gergen, L., Heavy metals health risk assessment for population via consumption of vegetables grown in old mining area, a case study: Banat County, Romania. Chem. Cent. J. 5, 64-73 (2011).

18. Gaetke, L.M., Chow, C.K., Copper toxicity, oxidative stress, and antioxidant nutrients. Toxicology 189, 147-163 (2003).

19. Isnard, H. La vigne en Algérie. Etude géographique. Ophrys, Gap, France (1951).

20. McGovern, P.E., Ancient Wine: The Search for the Origins of Viticulture. Princeton University Press, Princeton, NJ. (2004).

21. This, P.; Lacombe, T.; Thomas, M. R.; Historical origins and genetic diversity of wine grapes. Trends Genet. 22, 511-519 (2006).

22. International Organisation of Vine and Wine (OIV), statistiques viticoles mondiales, ISBN 979-10-91799-28-7 OIV (2011).

23. Afechtal, M., Bibi, I., Aarabe, A., Sbaghi, M., Ouantar, M., and Faddoul, Z., first report of grapevine leaf roll-associated virus 2 in Moroccan vineyards. Journal of Plant Pathology, 99 (2), 533-543 (2017).
24. Zaakour, F. and Saber, N., Assessment of Environnemental Quality in Soil under Wheat and Vines In Mohammedia-Benslimane region of Morocco. LAP LAMBERT Academic Publishing (ISBN 978-613-9-86706-6) (2018). 25.Amami, B., Serge, D.M.,Rhazi, L.,Rhazi, M.,Bouahim, S., : Modern pollen- vegetation relationships within a small Mediterranean temporary pool (western Morocco), Review of Palaeobotany and Palynology (2010).

26. AFNOR. NF X31-107., Soil quality: Determination of the particle size distribution of soil particles: Pipette method. Theme: Physical properties of soils (2003).

27. Walkley, A. and Black, I.A., An examination of the Degtjareff method for determining organic carbon in soils: Effect of variations in digestion conditions and of inorganic soil constituents, SoilSci. 63:251-263 (1934).

28.ISO 11265:1994 Soil quality - Determination of the specific electrical conductivity Specifies an instrumental method for the routine determination of the specific electrical conductivity in an aqueous extract of soil.

29. Mc Lean, E.O., pH and lime requirements. In: Page, A.L. et al. (Eds.), Methods of Soil Analysis, Part 2, second ed., Agronomy, vol. 9 Soil Society of America, Madison, WI, pp. 199244 (1982).

30. Bernard method described by Chamley., Guide of the techniques of the laboratory of Marine Geology of Luminy, (1966) .198p.

31. Brallier, S., Harrison, R.B., Henry, C.L., Dongsen, X., Liming effects on availability of $\mathrm{Cd}, \mathrm{Cu}, \mathrm{Ni}$ and $\mathrm{Zn}$ in a soil amended with sewage sludge 16 years previously. Water, Airand soil Pollution, (1996). 86, 195-206.

32. Baize, D., Total content of metallic trace elements in soils (France). Reference set interpretation strategies. INRA Editions, Paris $410 \mathrm{p}$ (1997).

33. Marschner, H., Mineral nutrition in higher plants. Wd Ltd. The Greystone Press, Antrim, Northern Ireland (1986).

34. Römheld, V., and Marschner, H., Genotypical differences among graminaceous species in release of phytosiderophores and uptake of iron phytosiderophores. Plant and Soil 123, 147-153 (1990).

35. Cakmak, I., Ekiz, H., Y1lmaz, A., Torun, B., Köleli, N., Gültekin, I., Alkan, A., and Eker, S. Differential response of rye, triticale, bread and durum wheats to zinc deficiency in calcareous soils. Plant Soil 188:1-10 (1997).

*Corresponding author: zaakour-fatna@ hotmail.com 
36. Cakmak, I. Effects of zinc fertilization and irrigation on grain yield and zinc concentration of various cereals grown in zinc-deficient calcareous soil. J. Plant Nutr. 21:2245-2256 (1998).

37. Rengel, Z., and Romheld, V., Root exudation and $\mathrm{Fe}$ uptake and transport in wheat genotypes differing in tolerance to $\mathrm{Zn}$ deficiency. Plant Soil, 222:25-34 (2000).

38. Kalayci, M., Torun, B., Eker, S., Aydin, M., Ozturk, L., Cakmak, I., Grain yield, zinc efficiency and zinc concentration of wheat genotypes grown in a zinc-deficient calcareous soil in field and greenhouse. Field Crops Res 63: 87-98 (1999).

39. Michaud, A.M., Interaction between bioavailability, phytotoxicity of copper, and iron nutrition of grasses- physiological rhizosphere mechanisms. In soil science. pp 191. Montpellier SupAgro, Montpellier (2007).

40. GültenYaylal1-Abanuz, Heavy metal contamination of surface soil around Gebze industrial area, Turkey, Microchemical Journal 99 (2011) 82-92, journal homepage: www.elsevier.com/ locate/microc (2011).

41. Alloway b.J. Heavy Metals in Soils. Chapman and Hall, London (1995).

42. McBride, A. M., Benitez, C., and Sherraden, M. The forms and nature of civic service: A global assessment (Research report). Center for Social Development, Washington University in St Louis (2003).

43. Tremel-Schaub A. and Feix I. Contamination des sols, transfert des sols vers les plantes, édition 2, $413 \mathrm{p}$ (2005).

44. Van Der Perk, M., P.N. Owens, L.K. Deeks, and B.G. Rawlins. Sediment geochemical controls on in-stream phosphorus concentrations during base flow. Water Air Soil Pollut.-Focus 6:443-451 (2006).

45. Navel, A., Distribution, speciation, impact and transfer of copper in vineyard soil: role of spatial structuring and organic status $\mathrm{PhD}$ Thesis, University of Grenoble (2011), 253P.

46.Morlot, M., Analytical aspects of lead in the environment, Ed Lavoisier TEC and DOC (1996).

47. Raskin, I., Ensley, B.D., Phytoremediation of toxic metals; using plants to clean up the environment". John Wiley and Sons, New York (2000).

48. Kabata-Pendias, Trace Elements in Soil \& Plants. CRC Press, Boca Raton, USA (2000).
49. Godin, sources of contamination and issues. Seminar: "Trace elements and soil pollution", 45 May 1982 Paris, PP 3-12.

50. Lee, C.G., Chon, H.T., Jung, M.C., Heavy metal contamination in the vincinity of the daduk Au-Ag-Pb-Zn mine in Korea. Applied Geochemistry, 16: 1377-1386 (2001).

51. El Morhit, M., Fekhaoui, M., Elie, P., Girard, P., Yahyaoui, A., ElAbidi, A., Jbilou, M., Heavy metals in sediment, water and the European glass eel, Anguilla Anguilla (Osteichthyes: Anguillidae) from Loukkos river estuary (Morocco eastern Atlantic). Cybium,33 (3), 219-228 (2009).

52. Chon et al., The myosin ATPase inhibitor 2,3-butanedione-2-monoxime disorganizes microtubules as well as F-actin in Saccharomyces cerevisiae. CellBiolToxicol 17(6):383-93 (2001).

53. Jung, M.C., Environnemental contamination of heavy metals in soils, plans, waters and sediments in the vicinity of metal liferous mine in Korea. Unpubl. PhD thesis, Univ, London, pp: 189-317 (1995).

54. Garcia, R., Millan, E., Assessment of $\mathrm{Cd}, \mathrm{Pb}$ and $\mathrm{Zn}$ contamination in roadside soils and grasses from Gipuzkoa (Spain). Chemosphere 37 (8) (1998).

55. Li, X J., The alkili-saline land and agricultural sustainable development of the western Songnen Plain in China. Scientia Geographica Sinica, 20(1): 51-55 (2000).

56. Lamy, J., Ducaroir, T., Sterckeman, F., Douay, T., Reactivity of organic materials. In Baize, D., Tercé, M., (Eds.) "Metallic Elements in Soils - Functional and Spatial Approaches" pp. 269-282, INRA-Éditions, Paris (2002).

57. Perrono, P., The metal micropollutants of sludge from urban sewage treatment plants and agricultural spreading. Mém. D.U.E.S.S., D.E.P., Univ. Picardie, Amiens (1999).

*Corresponding author: zaakour-fatna@ $($ hotmail.com 